\title{
Seçmen Tercihlerinin Yönlendirilmesinde Değer Odaklı Argümantasyon Kullanımı*
}

\author{
Using Value-Based Argumentation for Manipulating Voter Preferences
}

Osman ÇALIŞKAN ${ }^{* *}$
Emel POYRAZ

Öz

Seçmen tercihlerinin belirli bir siyasi kurum ya da görüş lehine yönlendirilmesi farklı birçok teknikle yapılmaktadır. Bununla birlikte, seçmenin ikna edilmesi sürecinde siyasi kurumun ürettiği mesajın belirli mantıksal ilkelere göre tasarlanması da genel bir zorunluluktur. Bu doğrultuda politik argümantasyon, bir taraftan mesajın taşıması gereken mantıksal şartları karşılarken bir taraftan da belirli teknik yapılar ve üslup özellikleri sunmaktadır. Bununla paralel olarak bu araştırmada, seçmen tercihlerinin yönlendirilmesinde değer odaklı argümantasyon kullanımı incelenmiştir. Bu kapsamda, 2017 yılında yapılmış olan “Cumhurbaşkanlığı Hükümet Sistemi Referandumu” uygulama alanı olarak seçilmiştir. AK Parti ve CHP’nin referandum kampanyası dahilinde ürettiği yazılı materyalin değer odaklı argümantasyon bağlamında politik argümantasyon analizi yapılmıştır. Araştırma sonucunda, referandum konularına yönelik üretilen toplam yedi AK Parti argümanından üçünün, CHP’nin ise toplam dokuz argümanından ikisinin değer odaklı argümantasyon tarzına uygun olduğu tespit edilmiştir.

Anahtar Kelimeler: Politik Argümantasyon, Değer Odaklı Argümantasyon, Yeni Retorik, Seçmen Tercihi, Siyasal İkna.

\section{Abstract}

Manipulating voter preferences in favor of a certain political institution or opinion is performed by a lot of different techniques. However, in the process of voter persuasion, it is also a general necessity that the message produced by the political institution is designed in compliance with certain logical

* Marmara Üniversitesi Sosyal Bilimler Enstitüsü Halkla İlişkiler Anabilim Dalı bünyesinde hazırlanan ve savunma tarihi Nisan 2018 olan doktora tezinden üretilmiştir.

** Dr., Pamukkale Üniversitesi, İletişim Fakültesi, Denizli, Türkiye, osmancaliskan@pau.edu.tr.

*** Doç.Dr., Marmara Üniversitesi, İletişim Fakültesi, İstanbul, Türkiye, emelpo@yahoo.com. 
principles. Accordingly; politic argumentation on one hand, meets logical qualifications that a message should have, on the other hand, it offers certain technical structures and wording features. In parallel with that, in this study, the use of value-based argumentation in manipulating voter preferences is examined. Within this framework, "Referendum of Presidential Government System" conducted in 2017 is selected as the object of research. In the context of value-based argumentation, political argumentation analysis has been carried out on written material that AK Party and CHP produced within referendum campaign. As a result of the research, it is determined that three of totally seven AK Party arguments, two of totally nine CHP arguments produced for referendum topics are in harmony with the value-based argumentation style.

Keywords: Political Argumentation, Value-Based Argumentation, The New Rhetoric, Voter Preferences, Political Persuasion.

\section{Giriş}

Seçmen tercihi konusu, sosyal bilimlerin üzerinde en çok söz edilen konularındandır. Farklı disiplinlerle kurduğu ilişki ve kendi içinde araştırmaların çeşitliliğinden kaynaklanan bir zenginlikten bahsetmek mümkündür. Bu çalışmanın sınırlarını aşacağından bahsi geçen tüm görüşlere yer vermek mümkün değildir. Fakat öncelikle konunun sosyo-psikolojik ayağına ve ardından da seçmen tercihi konusunda şimdiye kadar ortaya konmuş görüşlere ana hatlarıyla değinmekte fayda görülmektedir. Son olarak, tercihlerin yönlendirilmesi hususunda meselenin argümantasyon boyutu ele alınacaktır.

Tutumlar konusu, yukarıda da dikkat çekildiği üzere sosyo-psikolojik yönden araştırma konusuyla yakından bağlantılıdır. "Bugün tutum araştırmacıları, 'tutum’u doğrudan gözlenebilir olmasa da, davranışı önceleyen, eyleme ilişkin seçim ve kararlarımıza yön veren bir yapı olarak görmektedirler" (Hogg ve Vaughan, 2007, s. 174). "Eyleme ilişkin seçim ve kararlarımıza yön” vermesi hasebiyle tutumlar tercihte bulunma sürecinde ciddi bir öneme sahiptir. Kalıcı bir sistem olarak tutumların bilişsel, duygusal ve davranışsal olmak üzere üç temel öğesi bulunur (Freedman, Sears ve Carlsmith, 1989, s. 268). Bahsi geçen üç unsurdan bilişsel olanı argümantasyon konusuyla en yakın ilişki kuranıdır. Dolayısıyla seçmen tercihinin yönlendirilmesi, tutumlar konusu yönüyle politik argümantasyon sürecinde seçmen tutumlarının bilişsel yönüne etki etme gayretiyle ilişkilidir.

Tutumları inceleyen psikologlar ikna alanıyla da bağlantılı olarak tutum değişimini incelemişlerdir. Tabi bu yoğun ilginin pratik nedenleri vardır: Örneğin, siyasal tutumların değişmesi bir parti yerine diğerinin iktidar olmasını sağlayabilir (Cüceloğlu, 2014, s. 521-522). Bu araştırmalar kapsamında tutumlara yer verilmesi, dikkat çekildiği üzere ikna çalışmalarıyla olan ilişkisine bağlıdır. Bununla birlikte, ikna çalışmalarının daha çok argümantasyon boyutunun bizi ilgilendirdiğini de belirtmek durumundayız. Başka bir tabirle argümantatif mesaj tasarımı ikna edici iletişimin koşullarındandır. Belirli bir konuda ikna edilmeye çalışılan insanın ise farklı tutumları mevcuttur. Dolayısıyla ikna edilmek istenen hedef kitlenin sahip olduğu tutumları ve bu tutumların mahiyetini, nasıl değiştirilebileceğini bilmek önem arz etmektedir. 
Diğer yandan seçmen tercihleriyle ilgili çok farklı yaklaşımlardan bahsetmek mümkündür. Bu bakış açılarının, meseleyi ele alan disiplinin özelliklerine uygun bir hal aldığı görülmektedir. Yani seçmen tercihleri konusunu her bir çalışma alanı kendi perspektifinden ele almıştır. Kendi çalışma sahasının karakteristik özelliklerini aksettiren bu yaklaşımlar aşağıda kısaca aktarılmıştır.

Rasyonel tercih modeli, bireyi öne çıarır. Oy verme davranışını, seçmenin kendi çıkarlarını göz önüne aldığı oldukça rasyonel bir eylem olarak tanımlamaktadır. Diğer bir tabirle oy verme, desteklenen partiye duyulan bağllık ve sadakatten ziyade kişinin akılcı yöntemlerle belirlediği ve hedefe ulaşmasında ona yardım eden bir davranıştır (Heywood, 2013, s. 313). Rasyonel tercih modeli, bireyi içinde bulunduğu sosyolojik çevreden izole ettiği şeklinde bir eleştiriye maruz kalsa da ideolojilerin gücünü kaybettiğine yönelik öngörüye paralel olarak tutarlı bir yaklaşım sergilemiştir.

Sosyolojik yaklaşım, bireyin sosyal bir varlık olduğundan hareketle kendisini kuşatan ve şekillendiren her türlü toplumsal faktörün oy verme davranışlarına etki ettiği iddiasını taşır. İnsan siyasal bir tercihte bulunurken ferdi özelliklerinden çok grup aidiyeti, aile ve arkadaş çevresi, sahip olduğu inanç sistemi, yaşadığ coğrafya ve siyasal toplumsallaşma sürecinde iktidar tarafından aktarılan değerlerin etkisiyle hareket eder (Heywood, 2013, s. 312). Bahsi geçen sosyolojik unsurlar içerisinde toplumsal grupların aktardığı belirtilen değerlerin de bu araştırma kapsamında ayrı bir öneme sahip olduğunu belirtmeliyiz.

Kimi seçmen grupları için maddi çıarlardan ziyade inançlar ve idealler önemlidir. $\mathrm{Bu}$ durum seçmende partiye veya parti liderine karşı duygusal bağlllık oluşturur. Desteklenen partinin ya da liderin başarısı o kişiye tuttuğu takımın kazanmasına benzeyen ruhsal bir doyum sağlar. Kişi doyumu, kendisiyle aynı inancı paylaşanlarla bir arada olmaktan ve onlarla dayanışmaktan sağlar. Zaman içerisinde kişinin kendi ekonomik koşulları veya desteklediği partinin siyasi yönelimi değişse bile bağıllığın devam ettiği gözlemlenir (Kışlalı, 2000, s. 229). İşte bu doğrultudaki yaklaşım psikolojik model, parti kimliği modeli veya partiyle özdeşleşme modeli şeklinde adlandırılmaktadır.

Konuya oy verme yaklaşımı felsefi temellerini, özellikle bazı ülkelerdeki siyasi parti söylemlerinin birbirine çok benzediği düşüncesinden almaktadır. Buradaki vurgu, birbirine çok yakın siyasi parti programlarının seçmen nezdinde 'partiler arasında bir fark yok' gibi bir algıya sebep olmasınadır. Bu ise iddia edildiğine göre seçmenleri, partilerin ele aldıkları siyasi, kültürel veya ekonomik meselelere yaklaşımlarıly değerlendirildiklerini ve buna göre oy verdiklerini dile getirilmektedir (Converse, 1989, s. 127, 128). Bu bakış açısının birçok yönüyle rasyonel tercih modeline benzetildiğini de hatırlatmak gerekir.

Oy verme yaklaşımlarına daha radikal bir bakış açısı sergileyen ideolojik oy verme modeli ise, siyasi tercihlerin ideolojik manipülasyon ve kontrol ile şekillendiğini iddia eder. $\mathrm{Bu}$ kapsamda üretilen teoriler, oy verme davranışının kişinin içinde bulunduğu sosyal hiyerarşideki pozisyonunu yansıttığını söylemesi bakımından sosyolojik yaklaşıma benzetilmektedir. Bununla birlikte ideolojik modelde eğitim sistemi, devlet politikaları ve kitle iletişim araçları gibi faktörlere farklı bir işlev yüklendiği görülür (Heywood, 2013, s. 314). Bu model de, toplumsal 
sınıf farklılıklarından doğan yaşam biçimi ve ideolojik ayrılıkların getirdiği siyasal bakış açısına dikkat çekmesinden dolayı sosyolojik yaklaşıma benzetilmektedir.

Görüldügü üzere insanın sahip olduğu sosyo-psikolojik yapı, siyasal tercihlerin şekillenmesinde önemli rol oynamaktadır. Fakat bunların etki boyutlarını tayin etmek oldukça zor bir meseledir. Aynı teorinin belirli koşullar altında ve belirli bir ülke sınırları içinde farklı bir zaman diliminde yapılması bile sonuçların değişmesine sebep olabilecektir. Öte yandan bu araştırmanın sorunsalı, tercihlerin yönlendirilmesi sürecinde zaman ve mekan değişkenlerinden bağımsız olarak, değerlerdir. Özellikle sosyolojik ve ideolojik yaklaşımların dikkat çektiği üzere çalı̧̧ma, seçmenin benimsediği (ya da ona benimsetilen) değerlere odaklanmaktadır. Diğer bir anlatımla, seçmenin belirli bir bakış açısına yönlendirilmesi için kurulan argümantasyonda değerlerin kullanılması mercek alına alınmaktadır. Bu kapsamda aşă̆ıda, ileride yapılacak argümantasyon analizinin de teorik zeminini oluşturan değer odaklı argümantasyon konusuna ayrıntılı bir biçimde yer verilmiştir.

\section{Değer Odaklı Argümantasyon ve Yeni Retorik}

Bu başlık altında, Chaim Perelman ve Lucie Olbrechts-Tyteca’nın geliştirdiği "yeni retorik yaklaşımı” değer odaklı argümantasyon bağlamında ele alınacaktır. Perelman, Free University of Brussels'te hukuk ve felsefe üzerine eğitim almıştır (Gross ve Dearin, 2003, s. 1). OlbrechtsTyteca ise Perelman gibi yine Free University of Brussels'te okumuştur. Edebiyat, sosyoloji, sosyal psikoloji, istatistik gibi alanlarda çalışmıştır (van Eemeren, Garssen, Krabbe, Henkemans, Verheij ve Wagemans, 2014, s. 258).

Perelman’a (1979) göre yeni retorik bir argümantasyon teorisidir (s. 9-11). Argümantasyon ise her zaman, hatip (orator) diye adlandırılan kişi tarafından konuşma veya yazı yoluyla hedef kitle, dinleyici veya okuyucuya sunulan bir tez içerir. Burada amaç, hedef kitlenin ilgili teze bağlılığını sağlamak ya da ileri sürülen iddianın kuvvetlendirilerek yine hedef kitlenin onayını almaktır.

Yeni retorik yukarıda da dikkat çekildiği üzere başkalarını ikna etme çabası içinde olan rasyonel insanın zorunlu olarak argümantasyonu kullandığını varsayar. Analitik dışı düşünme tarzlarında ikna öğesinin merkeze alındığı kabul edildiğinde yeni retoriğin de bu temel karakteristik özelliğe sahip olduğu söylenebilir (van Eemeren, Garssen, Krabbe, Henkemans, Verheij ve Wagemans, 2014, s. 261-262). Aristoteles'in tasım mantığının dışında (non-analytic) kalan akıl yürütme tarzlarında rasyonelliğin boyutlarını arayan yeni retorik, akıl yürütmenin biçimsel olmayan yönünü ortaya koymaya çalışmıştır. Bu anlayış, basit gündelik konuşmalarda daha pratik (formel/biçimsel olmayan) bir akıl yürütme yapısının bulunduğunu savunur. Yeni retoriğin de en temel karakteristik özelliklerinden biri budur.

Perelman’n yeni retorik diye adlandırdığı yapının en temeline iknayı koyduğu yukarıda belirtildi. The New Rhetoric and the Humanities adlı eserinde Perelman (1979), bir tür "gelinen noktaya geri dönüş”ten bahseder. Perelman’a göre, Aristoteles’e ya da Aristoteles'in iknayı merkeze 
alan retorik anlayışına geri dönülmüştür. Şöyle ki, Antik dönemde retorik, ikna edici tartışma teorisi olarak sunulmuştur (s. 1-5).

Yeni retorik, sunduğu argüman taslakları, argüman çıkış noktası ve hedef kitle yaklaşımıyla diğer argümantasyon teorileri içinde ayırt edici bir yere sahiptir. Burada, araştırma sınırları içinde kalan çıkış noktası ve hedef kitle anlayışı müstakil başıklar altında detaylı olarak ele alınmaktadır. Fakat bunun öncesinde yeni retoriğe yöneltilen eleştirilere ana hatlarıyla yer vermekte fayda vardır.

Yeni retorik savunucularının ileri sürdüğü "formel mantığın argümantasyon çalışmalarına uygun olmadığı” yönündeki görüşler tahmin edileceği üzere klasik mantıkçlar tarafından eleştiriye uğramıştır. Formel mantığın ortaya koyduğu mirası küçümsemekle eleştirilen yeni retorik uzmanları köklü bir yapının temsilcileri tarafından reddedilmiştir (van Eemeren, Garssen, Krabbe, Henkemans, Verheij ve Wagemans, 2014, s. 290). Öte yandan 1960'larda gelişen informel mantık söylemi bu eleştiriyi oldukça zayıflatacak gerekçeler sunmuştur.

Yeni retoriğin eleştirilen kavramlarından biri "evrensel hedef kitle" olmuştur. Bir tartışmacının evrensel hedef kitlesi diğeri tarafından kabul edilmeyebilir. Ya da diğer deyişle, her bir tartışmacı kendi evrensel hedef kitle tarifini yapabilir (van Eemeren, Garssen ve Krabbe, 2014, s. 290). Öte yandan evrensel hedef kitle tanımlamasının ortaya koyduğu olgular, doğrular ve varsayımlara dayalı tasnif bu konuda genel bir yol haritası sunmuştur. En azından çoğunluğun kabul ettiği, belirli bilimsel ilkelere dayalı bir yapı ortaya konmuştur. Yeni retoriğin eleştirilen bir diğer önemli noktası ise insanın argümantasyon süreci içindeki rolünün zayıfllğı veya "ethos" öğesine hak ettiği önemin verilmediği iddiasıdır (van Eemeren, Garssen, Krabbe, Henkemans, Verheij ve Wagemans, 2014, s. 293). Yeni retorik, argümantasyon teorisini "logos" merkezli bir yapiya yaklaştırdığını zaten reddetmez. Hatta argümantasyonu daha nesnel bir zemine oturttuğunu ve dolayısıyla bunun ikna konusunda biliş dışı unsurlardan ziyade aklı önceliklediğini ifade etmiştir.

Bahsi geçen tüm eleştirilere rağmen yeni retorik, alana çok ciddi yenilikler sunmuştur. Klasik mantı̆̆ın ortaya koyduğu formel yapıyla argümantasyon çalışması yapılamayacağı yönündeki köklü iddiası başlı başına önemli bir etki yaratmıştır. Bu minvalde yapılan uzun soluklu çalışmalar klasik retoriğe yeni bir yüz ve içerik kazandırmıştır. Biçimci yapıdan olabildiğince uzaklaşarak politik metinlerden medya içeriklerine, gündelik konuşmalardan edebi eserlere kadar çok çeşitli dilsel yapının argümantasyon yönüyle incelenmesine olanak sağlayan belirli bir perspektif geliştirmiştir. Bu doğrultuda argüman çıkış noktası, özel ve evrensel hedef kitle kavramları, 30 civarında derlenen argümantasyon taslağı bunlardan sadece birkaçıdır. Özetlemek gerekirse, eleştiriye uğrayan yönlerine rağmen yeni retorik, dil ve ikna konusunda dış dünya gerçekliğine paralel bir kavrayışla kullanışı bir argümantasyon teorisi geliştirmiştir denilebilir.

\section{Yeni Retorikte Argüman Çıkış Noktası}

Argümantasyon işleminde ilk basamak, tüm argüman unsurlarının üzerine inşa edilebileceği bir zemin oluşturmaktır. Argümanın çıkış noktası (points of departure) veya başlangıç noktası (starting point) diye anılan bu ilk aşama oldukça önemlidir. Zira belirli bir konuda geliştirilen 
argümanın diğer unsurları bahsi geçen argüman çıkış noktasına dayandırılır. İlk olarak, argümanların çıkış noktasının en genel şekliyle ikili bir tasnife tabi tutulduğu belirtilmelidir. Bunlardan "gerçek ${ }^{1}$ " şeklinde isimlendirilen ilk kategori, olgular, doğrular ve varsayımlardan oluşurken evrensel hedef kitleye yönelik argümantasyonda kullanılır. İkinci kategori ise "yeğlenen" olarak adlandırılır. Bu kategoride ise değerler, değerler hiyerarşisi ve loci bulunurken özel hedef kitleye yönelik argümantasyonda kullanılır.

Perelman (1979), ilk kategoride yer alan olgular ve doğruların halihazırda evrensel hedef kitle tarafından doğru kabul edilerek üzerinde uzlaşılmış yapılar olduğunu belirtir. Bu sebeple bir olgu ve yahut doğrunun sorgulanması ve ona olan inancın arttırılması gibi bir çabaya da gerek yoktur. Çünkü her akıl sahibi varlık bunu kabul etmiştir. Varsayımlar ise kanıtlanmaya ihtiyaç olmayan düşüncelerdir. Öte yandan varsayımlar güçlendirilebilir veyahut ilgili varsayımın zıddının bastırılması/zayıflatılması yoluna gidilebilir (s. 15).

Yeni retorik çerçevesinde olgu, meydana gelmiş olan ya da varlığı bilinen şey anlamında kullanılır. Bu var olma hali deneyle, gözlemle veya farklı bilimsel yöntemler yoluyla kanıtlanmış ya da kanıtlanabilir olana gönderme yapar. Bu yönüyle olgu kavramı farklı bir anlamda değil pozitivist bilim anlayışı çerçevesinde kullanılır. Seyler’e (2008) göre olgular üzerinde genellikle tartı̧mayız. Mesela, "Profesör Jones'un Amerikan Edebiyatı dersi pazartesileri saat 10:00'da başlar” ibaresi tartışmaya mahal vermeyecek şekilde açıktır. Bunu, ders programını kontrol etmek suretiyle kolayca doğrulayabiliriz (s. 67). Bu sebeple yeni retorik evrensel hedef kitleye yönelik argümantasyonda olguları birer başlangıç noktası olarak kabul eder. Bununla birlikte doğru kavramı da yine olgu kavramında olduğu şekliyle kullanılır. Doğrular, dış dünya gerçekliğine dair farklı bilim alanlarının hüküm verdiği şeylerdir. Yeni retorik çerçevesinde bir doğrunun ileri sürülen argümantasyonda başlangıç noktası yapılması mümkündür. Yeni retoriğe göre varsayımlar da, doğru ve olgular gibi evrensel hedef kitleye yönelik argümantasyonda kullanılan diğer başlangıç noktası öğelerindendir. Varsayımlar, ortak tecrübe ve ortak sezgiye göre olağan koşulların hakim olduğu ortamda bireyin gerçeği idrak etmesi için ona bir yol sunar (Amador, 1999, s. 74). Rasyonel düşünen bireyin ikna edici tartışmalarda merkeze aldığı unsurlardan biri de varsayımlardır (Gross ve Dearin, 2003, s. 41). Böylelikle yeni retorikte başlangıç noktası kategorilerinden "gerçek" öğesi altında yer alan unsurlar ele alındı. Bu kategori, araştırmada ele alınan argümantasyon türünde başlangıç noktası olarak kullanılmadığından bu açıklamayı yeterli görüyor değer odaklı argümantasyonda kullanılacak yeğlenen kategorisine geçiyoruz.

Perelman ve Olbrechts-Tytecảnın iki kategori olarak tasnif ettiği ve ikinci kategoride (yeğlenen) yer alan değer ve değerler hiyerarşisinin ${ }^{2}$ bu araştırmada odak noktası olduğu çeşitli

1 Orijinal eserde "The Real" kelimesi kullanılmış. "The Real"i biz "Gerçek" olarak çevirdik. Fakat bu kategori kapsamına ("Gerçek" kategorisine) alınan "Truth"u ise gerçek değil de "Doğru” şeklinde kullanmayı uygun bulduk. $\mathrm{Bu}$, "bilimsel doğrular" gibi anlaşılabilir.

2 Araştırmanın analiz kısmında yer alan argümanlarda tespit edilen değerler "alana bağlı" ya da "saha temelli" değerlerdir. Diğer tabirle siyaset sahasına ait değerlerdir. Örneğin, demokratik yönetimlere atfedilen tartışmacı veya uzlaşmacı yaklaşım, ifade özgürlüğü, çoğulcu yaklaşım gibi. Hemen belirtmeli ki örneğin sosyal alana ait bir değer, siyasi alanda üretilmiş bir argümanın başlangıç noktası da yapılabilir.

Yukarıdaki açıklamalara ek olarak, değerler ve değerler hiyerarşisi konusunda tespitte bulunmak bu araştırmanın 
vesilelerle vurgulandı. Van Eemeren, Garssen, Krabbe, Henkemans, Verheij ve Wagemans'a (2014) göre değerler, belirli bir hedef kitlenin diğerinin karşıtı olarak herhangi bir şey, bir eylem veya bir duruma dair tercihlerini yansıtır. Değerler, karar verme konusunda yol haritaları gibidir. Şu durumda olduğu gibi: "Kişisel güvenlik önemlidir; bu sebeple daha fazla polis istihdam edecek partiye oyumu vereceğim.” Değerler aynı zamanda düşüncelerin şekillendirilmesinde de merkezi bir rol oynar. Şu örnekteki gibi: "Üzüm suyunu kolaya tercih ederim çünkü doğal ürünlerden hoşlanıyorum." Tartışmacı, değerlerden sadece bir eylem, bir durum veya bir şeyler arasından seçim yapmak için değil aynı zamanda yapılan bir seçimi haklılaştırmak için de istifade eder (s. 268).

Tasnif edilmiş bir hedef kitlenin değerlerinden hareketle bir argüman çıkış noktasının ilgili kitle tarafından kabul edilip edilemeyeceği önceden kestirilebilir. Örneğin inşa edilecek bir binayı ele alalım. Karakteristik eğilim olarak, muhtemelen bir yatırımcı bu binanın karlılık değeriyle (value of profitability), sanatseverler ise estetik değeriyle (value of beauty) ilgileneceklerdir. Dolayısıyla belirli sosyal veya siyasal grupların değerleri göz önünde bulundurularak onların hangi argüman çıkış noktasını kabul edeceği, hangisini reddedeceği tahmin edilebilir (van Eemeren, Garssen, Krabbe, Henkemans, Verheij ve Wagemans, 2014, s. 268).

$\mathrm{Bu}$ bölümün diğer önemli yönü ise değerler hiyerarşisidir. Hatta bu konu van Eemeren, Garssen, Krabbe, Henkemans, Verheij ve Wagemans’a (2014) göre değerlerin kendisinden bile önemlidir. Şöyle ki, ayrı hedef kitleler tarafından aynı değerler paylaşılsa bile değerlerin hedef kitleye göre öncelik sırası, yani değerler hiyerarşisi farklılık gösterebilir. Yukarıda verilen bina örneğini ele alacak olursak, her iki hedef kitle de hem karlılık değerine ve hem de binanın estetiğine önem verebilir. Fakat büyük olasılıkla bunların öncelik sırası farklıdır. Yatırımcılar için karlılık değeri öncelikliyken sanatseverler için binanın estetik değeri önceliklidir (s. 268).

Toplumsal kesimlere göre farklılık gösteren değerler hiyerarşisi özellikle siyasal alanda ve seçmenlerin oy tercihleri üzerinde çok ciddi sonuçlar ortaya çıkarmaktadır. Örneğin eğitim, savunma ve ekonomi gibi alanlar hemen her kesimden insanın önem verdiği konulardır. Fakat bu konulara verilen önem derecesi kimin hangi toplumsal ve siyasal kesimden olduğuna bağlı olarak değişmektedir. Ayrılıklar da burada başlamaktadır. Hatta fikri çatışmalar, siyasal tercihlerdeki ayrışmaların zeminini teşkil etmektedir. Yukarıda zikredilen alanları göz önünde bulundurarak ekonomiyi ele alalım. Ekonomik gelişim adına, nükleer enerji veya hidroelektrik santralleri kurma düşüncesi bir kesime iyi bir fikir gibi gelirken, çevre hassasiyeti yüksek bir grup için bu fikir kendi değerler hiyerarşisinde

amacı dışındadır. Hangi seçmen grubunun hangi değerlere sahip olduğu veya seçmen grupları arasında spesifik bir değerin hangi sırada yer aldığı araştırılmamaktadır. Bununla birlikte, aynı seçmen kitlesi içinde bir değerin yine aynı grubun üyeleri içindeki hiyerarşik yapısı da konu edilmemektedir. Bu araştırma kapsamında değer ve değerler hiyerarşisi şu yönüyle önemli ve ele alınmaktadır: Mesaj kaynağı (siyasal partiler), mesajını ulaştırmak istediği hedef kitlenin (seçmen) sahip olduğunu düşündüğü değerler ve değerler hiyerarşisine göre mesaj tasarımı yapma eğilimindedir. Ya da iletişim disiplini çerçevesinde mesajını bu şekilde dizayn etmesi ona etki anlamında güç kattığına inanılır. Mesaj kaynağı da hedef kitlede var olduğunu bildiği veya inandığı değerleri ve onların önem sırasını (hiyerarşisini) gözeterek mesajını dizayn eder. Seçmen gruplarının değerleri ve değerler hiyerarşisi ilgili sahalardaki uzamanlar, kamuoyu araştırmacıları tarafından tespit edilmiş olabilir veya ilgili siyasi parti kendi seçmen kitlesini değerler yönüyle tecrübe etmiş olabilir. 
gerilerde yer alacaktır. Öte taraftan, bir tehdit karşısında sıkı güvenlik önlemleri ve sert bir politika benimseyen bir gruba karşı diğer bir grup özgürlüklerin kısıtlanması ihtimali ve barışçıl bir dış politika tasavvuruyla buna karşı çıkabilir. Ya da muhafazakarlar ile laik kesim nezdinde eğitim meselesine bakış ve bunun değerler hiyerarşisindeki yerine göz atalım. Eğitimde dini ve milli unsurların arttırılması karşısında diğer taraf daha seküler bir eğitim programı talep edebilir. Görüldüğü gibi değerler hiyerarşisi seçmen tercihlerinin de şekillenmesine zemin oluşturmaktadır. Sonuç olarak bir tartışmada ele alınacak konunun, hedef kitle nezdinde değerler hiyerarşisindeki yeri iyi tespit edilmelidir. Böylelikle üretilen argümanların çıkış noktası da buna göre düzenlenebilecek ve arzu edilen etki yapılabilecektir.

Loci, Aristoteles'in Topikler ${ }^{3}$ adlı eserinin ana kavramlarından biridir. Loci ya da topoi, olası bilginin aleti olarak tanımlanan diyalektiğin esası sayılır. Loci, bir argümanda öncül mahiyetinde kullanılabilecek önermeleri içeren "müşterek yerler koleksiyonu" olarak tanımlanır (Tricot, 1996, s. i). Başka bir anlatımla, argüman sahibinin argümanını inşa etmesinde kullanabileceği belirli ifadelerden oluşur (Lauer, 2004, s. 167). Ya da yeni retorik terminolojisinden hareketle loci, bir argümanda başlangıç noktası yapılabilecek unsurdur (Smith, 2013, s. 349). Diyalektik akıl yürütme tarzında geliştirilen argümanlara zemin hazırlamak ya da argümanda belirtilen iddianın nedenlerini ortaya koymak üzere genellikle daha evvelden kabul görmüş genel geçer ifadeleri ve bunların temin edilebileceği yerleri (çünkü aynı zamanda 'yerler' anlamına da gelir) loci kapsamında değerlendirmek mümkündür.

\section{Yeni Retorikte Hedef Kitle Anlayışı}

Yeni retorik yaklaşımının can alıcı yönlerinden biri, hatibin mesajlarını ulaştırmak istediği muhatabına (audience) ya da hedef kitleye ${ }^{4}$ dair bakış açısıdır. Mesaj kaynağı, ürettiği mesajla hedef aldığı kitle üzerinde etki etmeye, arzu edilen yönde düşünce ve davranış değişikliği oluşturmaya çalışrr. İşte bu bağlamda, mesajin iletileceği kitle ve onun özellikleri iletişimin başarıya ulaşması adına son derece önemlidir. Nitekim Perelman ve Olbrechts-Tyteca (1971), argüman oluşturmak için, argümanı iletmek istediğimiz muhatabımız hakkında mutlak surette bilgi sahibi olmamız gerektiğine dikkat çeker (s. 18).

Perelman ve Olbrechts-Tyteca, evrensel hedef kitle (universal audience) ve özel hedef kitle (particular audience) olmak üzere ikili bir hedef kitle ayrımı yapmaktadır. Olgular, doğrular ve varsayımlar evrensel hedef kitle için üretilen argümanlarda çıkış noktalarını oluşturur (Gross ve Dearin, 2003, s. 41). Bahsi geçen tarzda bir hedef kitle, normal addedilen tüm erişkin insanları kapsar (Perelman ve Olbrechts-Tyteca, 1971, s. 30). Hatta bu sebepten bilim ve felsefe, kullandığ dili buna göre şekillendirir ve bu iki alanın hedef kitlesi de evrensel hedef kitle sayllır (Gross ve Dearin, 2003, s. 38).

3 Aristoteles'in Topikler adlı eserinde topoi (kavramın tekili: topos) dediği kavramı Chaim Perelman ve L. OlbrechtsTyteca (1971) loci (kavramın tekili: locus) şeklinde kullanmaktadır. İlk zikredilen Grekçe, ikincisi ise Latince'dir. Aralarında anlam bakımından fark yoktur.

4 Audience kelimesi iletişim sürecinde kaynağın mesajlarını iletmek istediği alıcıya denk düşer. Bu, diğer bir tabirle konuşanın, yani hatibin muhatabıdır. Burada audience kelimesi "hedef kitle" ile karşılanacaktır. 
Özel hedef kitle ise, toplumsal yapının herhangi başka bir parçası olabilir. Bu kitleye yapılan konuşmalarda değerler merkezi bir yer işgal eder (Gross ve Dearin, 2003, s. 42). Perelman ve Olbrechts-Tyteca, Türkçede "ikna etmek" şseklinde karşıladığımız persuade ve convince kelimeleri arasında anlam bakımından ayrım gözetirler ${ }^{5}$. İkinci kelimeyi, evrensel hedef kitlenin inandırılması için, ilk zikredilen kelimeyi ise özel hedef kitlenin iknası için kullanırlar (van Eemeren, Garssen, Krabbe, Henkemans, Verheij ve Wagemans, 2014, s. 264). Yeni retorik perspektifinden persuade kapsamındaki ikna, daha çok gündelik yaşamımızda karşılaştı̆̆ımız, üretilen argümanların çıkış noktasını değerlerin oluşturduğu ve karşıdakine belirli bir düşünceyi kabul ettirme gayesi güden tartışmalarda görülür.

Evrensel hedef kitle ve özel hedef kitle arasındaki fark, "gerçek" ve "tercih olunan" arasındaki fark gibidir. Şöyle ki, evrensel hedef kitleye yönelik yapılan konuşmalar gerçeğe odaklanırken özel hedef kitleye yönelik yapılan konuşmalar tercihlere veya tercih olunana odaklanır. Evrensel hedef kitlede konuşmacının muhatabı erkek ya da kadın, Amerikalı veya Cumhuriyetçi, Katolik veya Yahudi değil akılcı bir varlık olarak insanoğludur (Gross ve Dearin, 2003, s. 36). Özel hedef kitlede ise, ilgili grubun paylaştığı değerler ve bu değerlerin tartışmada kullanılması söz konusudur. Daha önce de vurgulandığı gibi, özel hedef kitleye dair üretilen argümanların çııış noktasını değerler oluşturur. Buna karşıt olarak Hester ve Hester (2010), evrensel hedef kitlede doğruluk ve geçerliliğin ileri sürülen bir argümanı kabul etmede daha baskın olduğuna vurgu yapar (s. 57). Zira Aarnio (2012) da aynı fikirdedir. Ona göre evrensel hedef kitle aydın kimselerin karışımından oluşan ve doğrulama yeteneği olan insanlardan meydana gelir (s. 221). Evrensel hedef kitle, özel hedef kitlenin kendi arasında paylaştığı müşterek zeminden ayrılır. Buradan hareketle evrensel hedef kitle, özel hedef kitlenin dışında kalanı kapsar denilebilir (Tindale, 2004, s. 128). Diğer yandan evrensel hedef kitlenin anlaşmazlıkları karara bağlama adına rasyonel bir zemin sağladığı belirtilir (Porter, 1998, s. 48). Çünkü çekişmeli bir konuda evrensel hedef kitlenin alanı, tercih olunanla alakalı olmayan kısmı kapsamaktadır. Örneğin kişisel tercihler, estetik içerikli konular veya dini temelli bazı kabuller gibi.

\section{Cumhurbaşkanlığı Hükümet Sistemi Referandumu'nun Politik Argümantasyon Analizi}

Aşağıda, öncelikle araştırmanın amaç, yöntem, kapsam ve sınırlılıkları gibi bilgilere yer verilecektir. Ardından Cumhurbaşkanlı̆̆ı Hükümet Sistemi Referandumu’nun değer odaklı politik argümantasyon analizi yapılacaktır.

5 Yeni retorikte "convince" dahilinde tanımlanan ikna, anlam alanı olarak, aklı başında, reşit, makul veya normal zihinsel sağlığa sahip insanların belirli alanlarda ve belirli argüman çıkış noktalarıyla inandırılmasına vurgu yapar. $\mathrm{Bu}$ argümanların çıkıs noktası olarak olgular, doğrular ve varsayımlar sayılabilir. Alan olarak ise felsefe ve bilim bunlardan sayılır. "Persuade" tarzda bir iknada ise argüman çıkış noktalarında genel olarak değerlerin kullanıldığı bir ikna türünden bahsetmek mümkündür. Alan olarak, gündelik yaşamımızda karşılaşacağımız herhangi bir tartışma vaya satışa yönelik bir ikna faaliyeti bu kapsamda değerlendirilebilir. 


\section{Araştırmanın Yöntemi}

Çalışmada, siyasal iletişim kampanyalarında değer odaklı argümantasyon kullanımına yönelik bir politik argümantasyon analizi yapılacaktır. Bu analizin esasını ve çerçevesini belirleyen bilimsel ilkeler daha evvelden tanıtılan yeni retorik yaklaşımına dayanmaktadır.

Yeni retoriğin ortaya koyduğu argümantasyon tekniği kolay okuma ve verilerin sistematik bir şekilde değerlendirilmesi adına bir tabloya aktarılmıştır. Tabloda yeni retorik anlayışının esasını oluşturan ana unsurlara yer verilmiştir. Bunları şöyle açıllayabiliriz: Öncelikle ve teknik bir gereklilik olarak tabloda analiz edilecek iddia ve/veya argümantasyon metninin yer aldığını belirtmeliyiz. İkinci olarak, argümanın hedef kitlesi yer almaktadır. Bu unsur, mesajın daha ilk basamakta nasıl inşa edilmesi gerektiğini tayin eden ikili bir ayrım noktasına (evrensel hedef kitle ve özel hedef kitle şeklinde) vurgu yapar. İşte buradan, incelediğimiz argümanın mesajhedef kitle ilişkisini ortaya çıkarmaya çalışacağız. Tabloda yer alan diğer unsur ise, argüman çıkış noktasıdır. Yeni retorik anlayışında çıkış noktaları gerçek ve yeğlenen şeklinde ikiye ayrılmıştır.

\section{Araştırmanın Amacı}

Siyasi partiler tartışmalı bir konuda seçmeni razı etmek için ikna gücü yüksek mesajlar üretme gayreti içerisindedirler. Bunu yaparken düşünceyi ifade eden dilsel yapının sistematik bir şekilde kodlanması lazım gelir. İkna edici iletişimde bunu sağlayan unsurlardan biri ise argümantasyondur. Argümantasyon, çıkış noktaları farklı olmak üzere birçok alandan istifade eder. Bilimsel doğrular, olgular veya varsayımlar olabileceği gibi değerler de bir argümanın çıkış noktasını oluşturabilir. İşte bu araştırmayla, Türkiye'de 2017 yılında yapılan referandum üzerinden değer odaklı argümantasyon kullanımı analiz edilecektir. Böylelikle Türkiye'de siyasi söylemin inşası noktasında değerlerin argümantatif mesaj tasarımındaki yerine dair bir fikir oluşturulabilcektir.

\section{Araştırmanın Sorunsalı}

Siyasi partiler, siyasal iletişim kampanyalarıyla seçmenin siyasal tutum, davranış ve oy tercihleri üzerinde etki etmeye çalışırlar. Bu ikna sürecinde benimsenen mesaj stratejileri önemli bir yer tutar. Bu bağlamda köklü bir çekişme olan rasyonel-irrasyonel (ethos ve pathos karşısında logos) tartışması karşımıza çıkar. Yani bir hatip (kaynak) mesajın yapısını hangi ilkeye göre oluşturursa daha etkili olur? Mesajın rasyonel boyutu mu ön plana çıkmalı yoksa mesajda irrasyonel öğeler mi yoğun olmalıdır? Mesajda sanatsal öğelere ne düzeyde yer verilmelidir? Estetik kaygı gerekli midir? Bir tarafa değerler ve inançları, diğer tarafa olgular ve doğruları koyduğumuzda mesajın içeriği bu iki tarafla nasıl ilişkilendirilmelidir? En nihayetinde ise, seçmen tercihlerinin yönlendirilmesinde (seçmenin ikna edilmesinde) tartışmacı yapı ve bu yapıyla bağlantılı olarak rasyonel öğelerin haricinde konumlandırılan değerlerin kullanımı bu araştırmanın sorunsalını oluşturmaktadır. 


\section{Araştırmanın Kapsamı ve Sınırlılıkları}

Çalışmada, yakın dönem Türk siyasi tarihinin dönüm noktalarından sayılan başkanlık sistemi referandumu ya da resmi adıyla Cumhurbaşkanlığı Hükümet Sistemi Referandumu uygulama alanı olarak tespit edilmiştir. Türk siyasetinde referandum çerçevesinde üretilen söylemlerin değer odaklı politik argümantasyon analizi yapılacaktır. Analizde kullanılacak argümanlar, iktidarda olan Adalet ve Kalkınma Partisi (AK Parti) ile ana muhalefeti temsil eden Cumhuriyet Halk Partisi’nin (CHP) ürettiği söylemden derlenecektir. İlgili söylem çerçevesinde ortaya çıkan argümanlar partilerin referandum kampanyası dahilinde oluşturdukları yazılı materyalden (kitapçık, broşür, v.s.) oluşmaktadır.

İlgili referandum kapsamında tartışılan tüm konular 9 ana başlığa ayrılarak ele alınmıştır. Bunlar şöyledir: 1) Kuvvetler Ayrılığı, 2) Denge ve Denetleme Mekanizması ve Unsurları, 3) Yürütme Organının Yetkileri, 4) Yürütme Organının Cezai Sorumluluğu, 5) Rejim Değişikliği, 6) Yarg1 Sistemi, 7) Kararnameler, 8) Üniter Yap1, 9) Partili Cumhurbaşkanı. Bahsi geçen bu dokuz başlık kapsamında AK Parti 3, 7 ve 9 numaralı başlıklarda değer odaklı argümanlara başvurmuştur. CHP ise, 3 ve 5 numaralı başlıklar kapsamında değer odaklı argümantasyonu kullanmıştır. Partilerin diğer başlıklar kapsamında ürettiği argümanlar modelimizdeki olguları, doğruları ve varsayımları içine alan "gerçek" kategorisinde değerlendirilmiştir. Dolayısıyla bu çalışma kapsamında analize dahil edilmemiştir.

\section{Cumhurbaşkanlığı Hükümet Sistemi Referandumu'nun Politik Argümantasyon Analizi}

Araştırmanın kapsamı kısımında da belirtildiği üzere iktidar ve muhalefet partileri üzerinden değer odaklı politik argümantasyon analizi yapılacaktır. Bu argümantasyon analizi referandumda "evet"i tercih eden AK Parti ile "hayır" tercih eden CHP arasında ortaya çıkan siyasi tartışmalar üzerinden iki blok olarak dizayn edilmiştir.

\section{AK Parti'nin Yürütme Organının Yetkileri Konusundaki Argümantasyonu}

Tablo I: AK Parti'nin Yürütme Organının Yetkileri Konusundaki Argümantasyonu

\begin{tabular}{|c|c|c|}
\hline $\begin{array}{l}\text { Argümantasyon Analizinin } \\
\text { Unsurları }\end{array}$ & $\begin{array}{l}\text { Analiz Edilecek } \\
\text { Argüman Metni }\end{array}$ & $\begin{array}{l}\text { Sunulan değişiklik teklifinde, yürütme organının başı olacak } \\
\text { cumhurbaşkanı ve ekibine en başında hükümet etme ve bu } \\
\text { doğrultuda çeşitli hak ve yetkiler tanınmış olup siyaseten etkin } \\
\text { ve güçlü bir ülke tesis etme amaçlanmıștır. }\end{array}$ \\
\hline Argümanın Çıkış Noktası & $\begin{array}{l}\text { Olgular } \\
\text { Doğrular } \\
\text { Varsayımlar }\end{array}$ & . $\mid \begin{array}{ll}\text { Yeğlenen } \sqrt{ } \\
- & \text { Değerler } \sqrt{ } \\
- & \text { Değerler Hiyerarşisi } \\
- & \text { Loci }\end{array}$ \\
\hline \begin{tabular}{|l} 
Argümanın Hedef Kitlesi \\
\end{tabular} & Evrensel Hedef Kitle & Özel Hedef Kitle $\sqrt{ }$ \\
\hline
\end{tabular}


AK Parti’nin yürütme organın yetkileri konusundaki argümanının "gerçek" ve "yeğlenen” kategorilerinden yeğlenen kategorisine uygun olduğu gözlemlenmektedir. Zira aşağıda detaylandırılacağı üzere çıkış noktası olarak değerlere başvurulduğu görülmektedir. Böylelikle AK Parti’nin, seçmen kitlesinin “özel” yönüne dair bir mesaj tasarladığı vurgulanmalıdır. Şu halde partinin hedef kitle tercihinin ise modelimizdeki "özel hedef kitle” tanımlamasına uygun düştügü belirtilmelidir.

Nitelikleri belirli iki hükümet sisteminin sonuçları bakımından hangisinin yeğlendiği/tercih edildiğiyle alakalı bir durum söz konusudur. Daha açık ifade etmek gerekirse, bir siyasi kararın müzakere sonucunda şeffaflık ilkesine bağlı kalınarak geniş bir katılımla alınması karşısında yetkileri kuvvetli dar bir kadro tarafından hızlıca alınması ve hayata geçirilerek yönetimde etkinliğin sağlanması değerleri karşısında hangisinin seçileceğiyle alakalı bir durumdur bu. AK Parti burada etkin yönetim anlayışından hareket etmiş, siyasi değerlerden ikinci sırada zikrettiğimizi benimsemiştir. Argümanın çıkış noktasını da özel hedef kitle anlayışına uygun olacak şekilde değerlerden hareketle oluşturmuştur. Yeğlenen değerlere bağlı olarak da geniş bir yetki düzenlemesi yapmıştır. Seçimleri yenileme, kararname çıkarma, üst düzey kamu görevlilerini atama ve görevden alma, bütçe yapma gibi yetkiler tanınmıştır. Özellikle kararnameler yoluyla önemli kamu kurumlarının yöneticilerini ve cumhurbaşkanı yardımcılarını atama gibi yetkilerin hükümetin hızlıca kurulmasını, bürokratik gecikmelerin önüne geçerek seri icraatlerin yapılmasını, kurumların gerekli halde yeniden yapılandırılmasını, terörle mücadelede etkinliğin sağlanmasını ve genel anlamda ülke ihtiyaçlarının ivedilikle giderilmesini sağlayacağı iddia edilmiştir. Tekrarlamak gerekirse AK Parti, yetki devriyle ilgili düzenlemeleri yeğlenen değerlere ve siyasi değerler sisteminden hiyerarşik olarak üstte tuttuğu değerlere bağlı olarak argümanın zeminini oluşturmuş ve kararı böyle meşrulaştırmıştır.

\section{AK Parti'nin Kararnameler Konusundaki Argümantasyonu}

Tablo 2: AK Parti'nin Kararnameler Konusundaki Argümantasyonu

\begin{tabular}{|c|c|c|c|}
\hline $\begin{array}{l}\text { Argümantasyon Analizinin } \\
\text { Unsurları }\end{array}$ & $\begin{array}{l}\text { Analiz Edilecek } \\
\text { Argüman Metni }\end{array}$ & \multicolumn{2}{|c|}{$\begin{array}{l}\text { Cumhurbaşkanına tanınan kararname çıkarma yetkisi, } \\
\text { yürütmeyi etkin ve hızlı bir hale getirerek ülkenin ve milletin } \\
\text { ihtiyaçlarına hızlıca cevap verebilmeyi sağlayacaktır. }\end{array}$} \\
\hline Argümanın Çıkış Noktası & \multicolumn{2}{|c|}{$\begin{array}{ll}\text { Gerçek } & \\
- & \text { Olgular } \\
- & \text { Doğrular } \\
- & \text { Varsayımlar }\end{array}$} & $\begin{array}{ll}\text { Yeğlenen } \sqrt{ } \\
- & \text { Değerler } \sqrt{ } \\
- & \text { Değerler Hiyerarşisi } \\
- & \text { Loci }\end{array}$ \\
\hline Argümanın Hedef Kitlesi & \multicolumn{2}{|c|}{ Evrensel Hedef Kitle } & Özel Hedef Kitle ل \\
\hline
\end{tabular}

En tartışmalı konulardan biri olan kararnameler hakkındaki AK Parti argümanının çıkış noktası, "gerçek” ve “yeğlenen” kategorilerinden yeğlenen özelliklerine uygun olduğu söylenebilir. Yürütme organının yetkileri konusundaki argümanda görüldüğü üzere kararname yetkisinde de 
aynı hedef kitle özelliğinden bahsetmek mümkündür. Bu tercihiyle AK Parti, seçmenin “özel” yönüne hitap etmiştir. Böylelikle hedef kitle bakımından modeldeki terminolojiye uygun olarak özel hedef kitle dahilinde değerlendirme yapmak mümkündür.

Belirli meselelerin mecliste uzun uzadıya tartışılarak karara bağlanmasındansa cumhurbaşkanının etkin ve hızlı icraat karşılığında kararname yayınlayabilmesi politik bir değer olarak kabul edilirse AK Parti burada hızlı ve etkin olmayı siyaseten bir değer addetmiş ve bu yönde tercihte bulunmuştur. Argümanın zeminine (çıkış noktası) yerleştirdiği bu durum üzerinden mesajını tasarlamıştır. Kısaca belirtmek gerekirse, hızlı ve etkin bir icraat önemsenmiştir. AK Parti, karar alma sürecinde demokratik katılımın sekteye uğrayabileceği yönündeki eleştirilerin önüne geçmek için de kararname çıkarma konusunda belirli kısıtlamalar yaptı̆̆ını vurgulamıştır. Örneğin kararname alanlarının sınırlandırıldığı ve genel anlamda çıkan kararnamelerin meclis ve Anayasa Mahkemesi'nin denetiminde olacağ 1 vurgulanmıştır.

\section{AK Parti'nin Partili Cumhurbaşkanı Konusundaki Argümantasyonu}

Tablo 3: AK Parti'nin Partili Cumhurbaşkanı Konusundaki Argümantasyonu

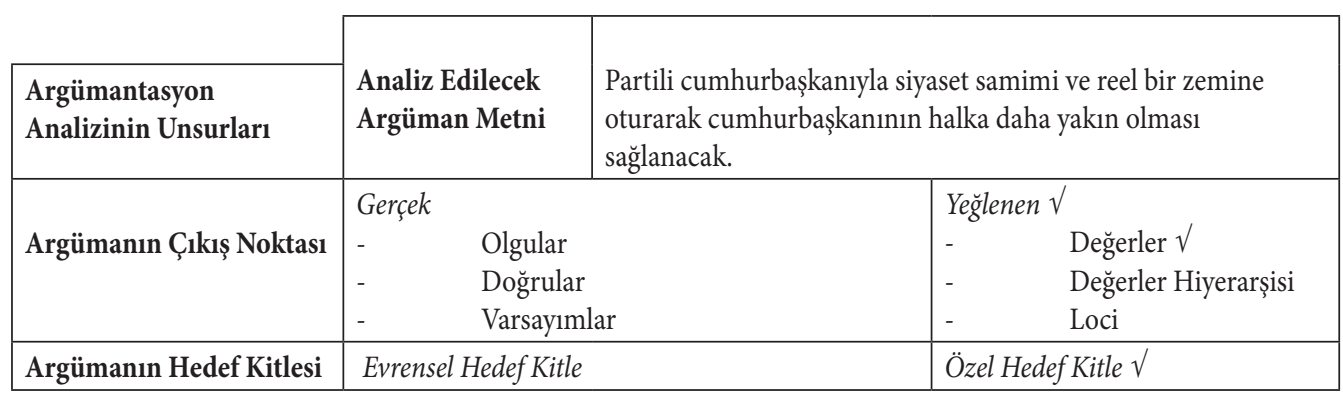

AK Parti’nin, partili cumhurbaşkanı konusundaki tartışmalara yönelik ürettiği argümanın çıkış noktasını “yeğlenen” kategorisine dahil etmek mümkündür. Bu özelliklere paralel olarak da argümanın hedef kitlesinin parti seçmeninin değerlerine hitap eden özel hedef kitle kategorisinde olduğu belirtilmelidir.

Referandumun yapıldığı tarihte yürürlükte olan sistem, cumhurbaşkanı adayının varsa partisinden istifa etmesini gerekli kılıyordu. Bunun yanında, cumhurbaşkanının siyasi kurumlarla ilişkisi tarafsızlık ilkesi kapsamında belirleniyordu. Siyasi kurumlar karşısındaki bu işleyiş yapısı ve anlayışı siyaseten bir değer addedilmiştir. Diğer yandan, referandumla önerilen sistemde ise cumhurbaşkanına partilere üyelik imkanı sağlanmaktadır. Cumhurbaşkanının partisiyle ilişkisinin devam ettirilmesi daha gerçekçi bir yapı olarak kabul edilmiştir. Buna ek olarak, cumhurbaşkanının parti üyeliği kanalıyla seçmenle kuracağı yakın ilişki siyasetin samimileştirilmesi adına önemli bir adım sayılmıştır. Bu iki husus, AK Parti tarafından siyasi bir değer addedilmiş ve seçmenin meseleye soğuk durmayacağı düşünülerek konuyla ilgili argümanının çıkış noktası yapılmıştır. 


\section{CHP'nin Yürütme Organının Yetkileri Konusundaki Argümantasyonu}

Tablo 4: CHP'nin Yürütme Organının Yetkileri Konusundaki Argümantasyonu

\begin{tabular}{|l|l|l|l|}
\cline { 2 - 3 } \multicolumn{1}{l|}{$\begin{array}{l}\text { Argümantasyon } \\
\text { Analizinin Unsurları }\end{array}$} & \multicolumn{2}{|l|}{$\begin{array}{l}\text { Analiz Edilecek Argüman } \\
\text { Metni }\end{array}$} & $\begin{array}{l}\text { Olağanüstü yetkilerle donatılan cumhurbaşkanı, siyasi ve } \\
\text { hukuki kurumlar arasindaki dengeyi bozarak mecliste, } \\
\text { yargıda ve diğer idari alanlarda mutlak hakimiyet kuracaktır. }\end{array}$ \\
\hline Argümanın Çıkış Noktası & $\begin{array}{l}\text { Gerçek } \\
-\quad \begin{array}{l}\text { Olgular } \\
\text { Doğrular } \\
\text { Varsayımlar }\end{array}\end{array}$ & $\begin{array}{l}\text { Yeğlenen } \sqrt{ } \\
\text { Değerler } \sqrt{ } \\
\text { Değerler Hiyerarşisi } \\
\text { Loci } \sqrt{ }\end{array}$ \\
\hline Argümanın Hedef Kitlesi & Evrensel Hedef Kitle & - & Özel Hedef Kitle $\sqrt{ }$ \\
\hline
\end{tabular}

CHP, bu konudaki argümanının çıkış noktasını "yeğlenen” kriterlerine göre dizayn etmiştir. Yetkinin bir kişi veya kurumdan diğerine devri, benimsenen siyasi tutum ve değerlerle ilişkilidir. Nitekim CHP, parlementer sistem ve onun esasını teşkil eden değeri savunmuştur. Bu kapsamda partinin, seçmen kitlesinin “özel” yönünü hedeflediği söylenebilir. Buna paralel olarak da argümanın hedef kitlesinin özel hedef kitle kategorisinde değerlendirilmesi gerektiği belirtilmelidir.

CHP, referandumla önerilen Cumhurbaşkanlığı Hükümet Sistemi'nin, cumhurbaşkanına sağladığı "olağanüstü” yetkiler sebebiyle bir “tek adam diktası”na dönüşeceğini savunmuştur. Kitapçıkta, bu minvalde birçok yetkiye dikkat çekilmiştir. Yardımcı, bakan ve üst düzey kamu görevlileri atama ve onları görevden alma, kararname çıkarma, kamu kurumu kurma ve kaldırma, fesih ve veto yetkisi, yüksek mahkemelere üye atama gibi cumhurbaşkanına sağlanan yetkilerden bahsedilmiştir. CHP’ye göre bu yetkiler, ABD örneği verilerek gösterilen başkanlık sitemi gibi bir siyasal yapının tesis edilmesi için çok ciddi engellerdir. Zira örnek verilen ABD tipi başkanlık sisteminde katı kuvvetler ayrılığı vardır ve Türkiye’de oylanacak olan sistem tamamen farklıdır.

\section{CHP'nin Rejim Değişikliği Konusundaki Argümantasyonu}

Tablo 5: CHP’nin Rejim Değişikliği Konusundaki Argümantasyonu

\begin{tabular}{|c|c|c|}
\hline $\begin{array}{l}\text { Argümantasyon } \\
\text { Analizinin Unsurları }\end{array}$ & $\begin{array}{l}\text { Analiz Edilecek Argüman } \\
\text { Metni }\end{array}$ & $\begin{array}{l}\text { Yeni sistemle yapılmak istenen, tıpkı otoriter rejimlerde } \\
\text { olduğu gibi egemenliğin tek elde toplanmasıdır. }\end{array}$ \\
\hline Argümanın Çıkış Noktası & 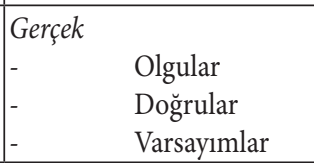 & 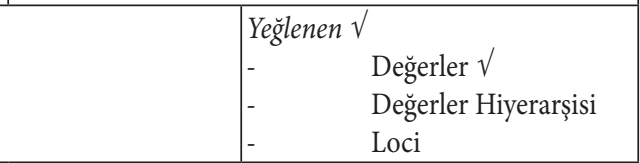 \\
\hline Argümanın Hedef Kitlesi & Evrensel Hedef Kitle & Özel Hedef Kitle $\sqrt{ }$ \\
\hline
\end{tabular}

CHP’nin bu tartışmadaki argümanının çıkış noktasını, benimsenen herhangi bir siyasi sistemin tercihi babında "yeğlenen" kategorisine almak mümkündür. Zira yürütmenin yetkileri tartışmasında vurgulandığı üzere, partinin parlamenter sistem ve onun değerleri konusundaki tercihleri söz konusudur. Anlaşıldığı üzere CHP bu argümantasyon üslubuyla seçmen kitlesinin 
“özel” yönünü etkilemeyi amaçlamıştır. Buna paralel olarak da argümanın hedef kitle özellikleri bakımından özel hedef kitleye uygun bulunduğu belirtilmelidir.

CHP, parlamenter sistem dişındaki bir modele topyekün karşı çıkmakla birlikte önerilen Cumhurbaşkanlığı Hükümet Sistemi’nde de problemler görmektedir. Özellikle yetkiler konusunu problematik hale getirmektedir. Dahası, "tek adam veya diktatörlük” tartışmasındaki argümanını da buna bağlamaktadır. Zira CHP’ye göre olağanüstü yetkiler bir “tek adam sultası” oluşmasına sebep olacaktır.

\section{Sonuç}

AK Parti'nin referandum kapsamında tartışılan konular dahilinde ürettiği toplam yedi argümanın üçü yeğlenen kategorisinde değerlendirilmiştir. Bu durum, partinin bilişsel faktörler dışında bir alanda, yani “özel hedef kitle” kapsamında bir argümantasyon yapısından da önemli ölçüde istifade ettiğini göstermektedir. Şöyle ki, AK Parti seçmeni tarafından "değer" addedilen bazı konuların partinin argümantatif mesaj tasarımında ciddi boyutlarda rol oynadığ söylenebilir. AK Parti yürütme organının yetkileri, kararnameler ve partili cumhurbaşkanı konularında bu kapsamda argümanlar üretmiştir. Bir değerler sistemi dahilinde, herhangi bir değere yüklenen öneme binaen, yine aynı değer tasarlanan argümanın zemini olmuştur. Örneğin demokratik yönetim anlayışının ortaya koyduğu değerler karşısında terör, iç karışıklık ve dış tehditler tehlikesine karşılık etkin ve hızlı karar alabilen bir hükümet sistemi değerleri yeğlenmiştir. Yukarıda adı geçen konularda üretilen argümanların zemini de yeğlenen bu değerlerden oluşmuştur. Bu noktada, seçmenin genel değerler profilinin stratejiyi belirlemede etkili olduğu unutulmamalıdır. Başka tabirle hedef kitlenin, argümanın çıkış noktasına konulan değerlere uzak olmadığı argümanı inşa eden tarafından bilinmektedir.

CHP’nin ise referandum kapsamında tartışılan dokuz başlık arasından iki adet argümanı yeğlenen kategorisinde değerlendirilmiştir. Bunun değerler ve değerler hiyerarşisi ile bağlantılı bir durum olduğunu belirttik. Bu durumun yine modelimizdeki özel hedef kitle unsuruyla bağlantılı olduğunu hatırlatmalıyız. Zira özel hedef kitle için hazırlanan mesajlar, belirli türden değerleri, alışkanlıkları, tutum ve davranışları paylaşan, büyük oranda türdeş bir alıcıya iletilir. Argümantatif mesaj tasarımında da durum aynıdır. CHP, “yürütme organının yetkileri” ve "tek adam rejimi” tartışmalarında bu yolu izlemiştir. Zira bu konulardaki çıkış noktasında parlemeter sistemle ilişkilendirilen değerlere yer verilmiştir. Çünkü seçmen kitlesinin bu değerlere uzak olmadığı varsayılmakta ve çıkış noktası oluşturulurken göz önünde bulundurulmaktadır.

Siyasal iknayı sağlamak adına, seçmenin bilişsel yönüne hitap eden bir mesaj tasarımı anlayışının yanında, bilişsel alan dışında kalan unsurların da gerekli ve hatta zorunlu olduğunu söyleyebiliriz. Toplumun tüm üyeleri tarafından paylaşılmasa bile belirli bir kesim tarafından yeğlenen bazı tutum ve davranış kalıplarının varlığı sosyolojik bir gerçekliktir. Değerlerin varlığı, toplumsal ve siyasi ilişkiler çerçevesindeki rolü de böyle bir gerçekliktir. İşte bu değerlerin, seçmen tercihinin yönlendirilmesi hususunda da aktif rol aldıklarını söylemek yanlış olmayacaktır. Yapılan bu araştırma kapsamında da siyasi kurumların bu gerçekliğin farkında olduğu, değerlere 
dayalı geliştirilen argümanların kampanya materyalinde belirli bir yer tuttuğu görülmüştür. Zira Türkiye’nin önemli bir siyasi meselesi üzerinde yürütülen tartışmalarda, seçmeni ikna etmek üzere sadece bilişsel sahaya dahil edilen argümanlar değil, değer odaklı bir argümantasyon anlayışından da istifade edilmesi bunu kanıtlar niteliktedir. 


\section{Kaynakça}

Aarnio, A. (2012). The rational as reasonable: A treatise on legal justification. Boston: Springer Science \& Business Media.

Amador, J. D. (1999). Academic constraints in rhetorical criticism of the new testament: An introduction to a rhetoric of power. Sheffield: Bloomsbury Publishing.

Converse, P. (1989). Kamuoyu ve oy verme davranışı. N. Nie, S. Verba ve P. Converse içinde, Siyasal katılma kamuoyu ve oy verme davranışı (İ. Turan ve T. Karamustafaoğlu, Çev., 96-208). Ankara: S Yayınları.

Cüceloğlu, D. (2014). İnsan ve davranışı. İstanbul: Remzi Kitabevi.

Freedman, J. L., Sears, D. O. ve Carlsmith, J. M. (1989). Sosyal psikoloji. (A. Dönmez, Çev.) İstanbul: Ara Yayıncilik.

Gross, A. ve Dearin, R. (2003). Chaim Perelman. New York: State University of New York Press.

Hester, J. D. ve Hester, J. D. (2010). Rhetorics in the new millennium: Promise and fulfillment. New York and London: A\&C Black.

Heywood, A. (2013). Siyaset. Ankara: Liberte Yayınları.

Hogg, M. A. ve Vaughan, G. M. (2007). Sosyal psikoloji. (İ. Yıldız, ve A. Gelmez, Çev.) Ankara: Ütopya Yayınları.

Kışlalı, A. T. (2000). Siyasal sistemler: Siyasal çatışma ve uzlaşma. Ankara: İmge Kitabevi.

Lauer, J. M. (2004). Invention in rhetoric and composition. Indiana: Parlor Press.

Perelman, C. (1979). The new rhetoric and the humanities. Dordrecht: D. Reidel Publishing Company.

Perelman, C. ve Olbrechts-Tyteca, L. (1971). The new rhetoric: A treatise on argumentation. London: University of Notre Dame Press.

Porter, J. E. (1998). Rhetorical ethics and internetworked writing. London: Greenwood Publishing Group.

Seyler, D. (2008). Read, reason, write an argument text \& reader. Boston: McGraw Hill.

Smith, C. R. (2013). Rhetoric and human consciousness. Illinois: Waveland Press.

Tindale, C. W. (2004). Rhetorical argumentation: Principles of theory and practice. London: SAGE Publications.

Tricot, J. (1996). Giriş. Aristoteles, Organon V: Topikler içinde (H. R. Atademir, Çev., i-ii). İstanbul: Milli Eğitim Basımevi.

van Eemeren, F., Garssen, B., Krabbe, E., Henkemans, A., Verheij, B. ve Wagemans, J. (2014). Handbook of argumentation theory. New York: Springer Reference. 